DOI: 10.14720/aas.2014.103.2.16

Agrovoc descriptors: vitis vinifera, grapevines, agrobacterium, hosts, vineyards, damage, genetics, genetic variation,pathogenicity,molecular biology,plasmids,cankers

Agris category code: h20

\title{
Comparative study of diagnostic methods used for monitoring of common grape vine (Vitis vinifera L.) crown gall (Agrobacterium vitis Ophel \& Kerr) in Slovenia
}

\author{
Janja LAMOVŠEK ${ }^{1}$, Igor ZIDARIČ${ }^{2}$, Irena MAVRIČ PLEŠKO ${ }^{3}$, Gregor UREK $^{4}$, Stanislav TRDAN ${ }^{5}$
}

Received April 24, 2014; accepted May 25, 2014.

Delo je prispelo 24. aprila 2014, sprejeto 25. maja 2014.

\begin{abstract}
Agrobacterium vitis causes common grape vine (Vitis vinifera L.) crown gall disease that destroyed a lot of Slovenian vineyards more than a decade ago. Eighty isolates of Agrobacterium spp. collected during monitoring in 2006 were identified as $A$. vitis and A. tumefacies by pehA and multiplex PCR method. Tumor-inducing capacity of these strains was assessed on test plants and with PCR methods for detection of the $\mathrm{Ti}$ plasmid responsible for tumor induction. With VCF3/VCR3 primer pair six false negatives and no false positives were detected. The high genetic diversity of pathogenic Agrobacterium spp. strains affects the performance of molecular methods, thus biological test should be performed where results from molecular methods are doubtful.
\end{abstract}

Key words: Agrobacterium vitis, common grape vine, host plants, pehA, multiplex PCR, VCF3/VCR3

\begin{abstract}
IZVLEČEK
PRIMERJAVA DIAGNOSTIČNIH METOD

SPREMLJANJA POJAVA RAKA (Agrobacterium vitis Ophel \& Kerr) ŽLAHTNE VINSKE TRTE (Vitis vinifera L.) V SLOVENIJI

Bakterija Agrobacterium vitis je povzročitelj raka žlahtne vinske trte (Vitis vinifera L). Ta bolezen je uničila mnogo slovenskih vinogradov pred več kot desetimi leti. V sklopu spremljanja pojava bolezni smo leta 2006 izolirali 80 izolatov, ki smo jih s PCR metodama pehA in multipleks določili kot vrsti A. vitis in A. tumefaciens. Sposobnost sevov, da izzovejo nastanek tumorjev, smo ocenjevali na gostiteljskih rastlinah. $\mathrm{Z}$ molekularnimi metodami pa smo določali prisotnost plazmida $\mathrm{Ti}$, povzročitelja nastanka tumorjev. $\mathrm{Z}$ metodo PCR smo ugotovili šest lažno negativnih patogenih sevov in nobenega lažno pozitivnega. Velika genetska raznolikost patogenih sevov Agrobacterium spp. vpliva na zanesljivost določanja $\mathrm{z}$ molekularnimi metodami, zato se $\mathrm{v}$ primeru dvomljivih rezultatov priporoča dodatna izvedba bioloških testov na rastlinah.
\end{abstract}

Ključne besede: Agrobacterium vitis, vinska trta, gostiteljske rastline, pehA, multipleks PCR, VCF3/VCR3

\footnotetext{
1 B.Sc. Microbiology, Agricultural Institute of Slovenia, Plant Protection Department, Hacquetova ulica 17, SI-1000 Ljubljana, Slovenia, e-mail: janja.lamovsek@kis.si

B.Sc., ibid.

3 PhD, ibid.

4 Assist. Prof., PhD, ibid.

5 Prof., University of Ljubljana, Biotechnical Faculty, Dept. of Agronomy, Jamnikarjeva 101, SI-1111 Ljubljana, Slovenia
} 


\section{INTRODUCTION}

Crown gall disease occurs worldwide and causes major economical losses in fruit and grapevine production (De Cleene and De Ley, 1976; Kennedy and Alcorn, 1980; Pulawska, 2010). The major part of income loss is attributed to crown gall on young grafted plants in nurseries. The disease is characterized by a tumor which is usually formed on a plant stem just above the ground. Still, the disease is rarely fatal. Mainly young or stressed plants develop more pronounced symptoms: loss of plant vigour, reduction in crop yield, or even plant death (Poncet et al., 1996; Epstein et al., 2008). The disease is problematic on perennial horticultural crops, such as grapevines, stone and pome fruit trees, and ornamental plants, where tumors weaken the plant year after year. The causal agents of the disease are pathogenic Agrobacterium spp. carrying the Ti plasmid (pTi) (Van Larebeke et al., 1974; Watson et al., 1975). The ability to cause tumors is encoded on a portion of the pTi (T-DNA) that integrates into the host genome. Upon expression, the T-DNA genes alter the level of plant hormones resulting in uncontrolled plant cell proliferation and tumor formation (reviewed in Escobar and Dandekar, 2003).

Traditional identification of Agrobacterium spp. is based on biochemical tests (Holt et al., 1994). The INCO-DC European program ERBIC18CT970198, "Integrated Control of Crown Gall in Mediterranean Countries" has presented an identification scheme for agrobacteria with minimal biochemical tests (reviewed in Shams et al., 2012). Additionally, accurate identification can be achieved by molecular methods. Eastwell et al. (1995) developed a PCR method for detecting A. vitis (Ophel and Kerr, 1990) - causative agent of crown gall of grapevines. The method targets chromosomal polygalacturonase gene that is found in A. vitis, but not in A. tumefaciens (Smith \& Townsend, 1907) Conn 1942 or A. rhizogenes (Riker et al. 1930) Conn 1942, which are rarely found in grapevine tumors. A decade later, Pulawska et al. (2006) developed a multiplex PCR for classification of Agrobacterium strains into $A$. tumefaciens, A. rhizogenes and A.vitis. This method amplifies the specific fragment on $23 \mathrm{~S}$ rRNA and enables rapid diagnosis of Agrobacterium species. These molecular techniques are based on bacterial DNA and are more specific, sensitive, rapid and suitable for diagnostics. The genetic diversity within genus Agrobacterium has recently led to reclassification of A. rhizogenes into genus Rhizobium (Young et al., 2006). On the other hand, A. tumefaciens and A. vitis were reported to differ from the members of the genus Rhizobium and therefore can remain in the same genus (Farrand et al., 2003, Lindström and Young, 2011). Additionally, genetically variable strains of $A$. tumefaciens, now termed $A$. tumefaciens species complex group, were clustered into genomospecies that will progressively be reclassified into new species (Mougel et al., 2002, Portier et al., 2006; Lindström and Young, 2011; Pulawska and Kalužna, 2012).

Effective detection of tumor-inducing agrobacteria in plant material is crucial in propagating material and efficient management of crown gall disease. Traditionally, bacteria are isolated from plant or soil material by cultivation on selective media followed by testing their tumor-inducing capacity on test plants. According to Schroth et al. (1971), this protocol is not sensitive or robust enough in comparison to molecular methods. Most molecular methods for detection of tumorigenic isolates target tumorigenicity genes on a conserved vir region on the pTi. Sawada et al. (1995) developed $\mathrm{VCF} / \mathrm{VCR}$ primers that target $\mathrm{pTi}$-encoded virC1 and virC2 genes. Suzaki et al. (2004) improved the specificity of the primers (VCF3/VCR3) for pathogenic Agrobacterium strains from apple seedlings, but the primers work on $A$. vitis strains as well (Kumagai and Fabritius, 2008).

Grape crown gall caused substantial damage to vineyards in the winegrowing regions of Slovenia in 1999 (Šabec-Paradiž et al., 2002). Much of the following Agrobacterium-based research in Slovenia was dedicated to control and prevention of $A$. vitis and $A$. tumefaciens infections on grapevine plants and propagating material, and also to characterization of $A$. vitis isolates in Slovenia (Fabjančič and Milevoj, 2003). In the present study we compared the Agrobacterium identification methods used for grape crown gall disease monitoring in Slovenia. 


\section{MATERIALS AND METHODS}

\subsection{Bacterial strains and isolates}

A crown gall monitoring was conducted in 2006. Eighty-seven symptomatic grapevine grafts (Figure 1) were collected from nurseries and vineyards from across various winegrowing regions of Slovenia. Eighty isolates of Agrobacterium spp. were obtained from plant material on 3DG medium semi-selective for $A$. vitis (Brisbane and Kerr, 1983). All 80 strains were subcultured on King's B medium (KB), pure cultures preserved in meat peptone broth with glycerol, and stored at $-80{ }^{\circ} \mathrm{C}$ until further use. All 80 strains were analysed in the diagnostic laboratory at Agricultural Institute of Slovenia.
Reference A. tumefaciens C58 (INRA, France), A. vitis 339-26 (IVIA, Spain) and Rhizobium rhizogenes K84 (IVIA, Spain) strains were used as controls in molecular and biological diagnosis.

\subsubsection{Preparation of bacterial DNA}

The bacterial DNA used in PCR reactions was extracted from $24 \mathrm{~h}$-old colonies grown on $\mathrm{KB}$ medium at $27{ }^{\circ} \mathrm{C}$. We used a standard alkaline lysis method (Sambrook et al., 1989), diluted the DNA $(1: 1000)$ in sterile distilled water and stored it at $20{ }^{\circ} \mathrm{C}$.

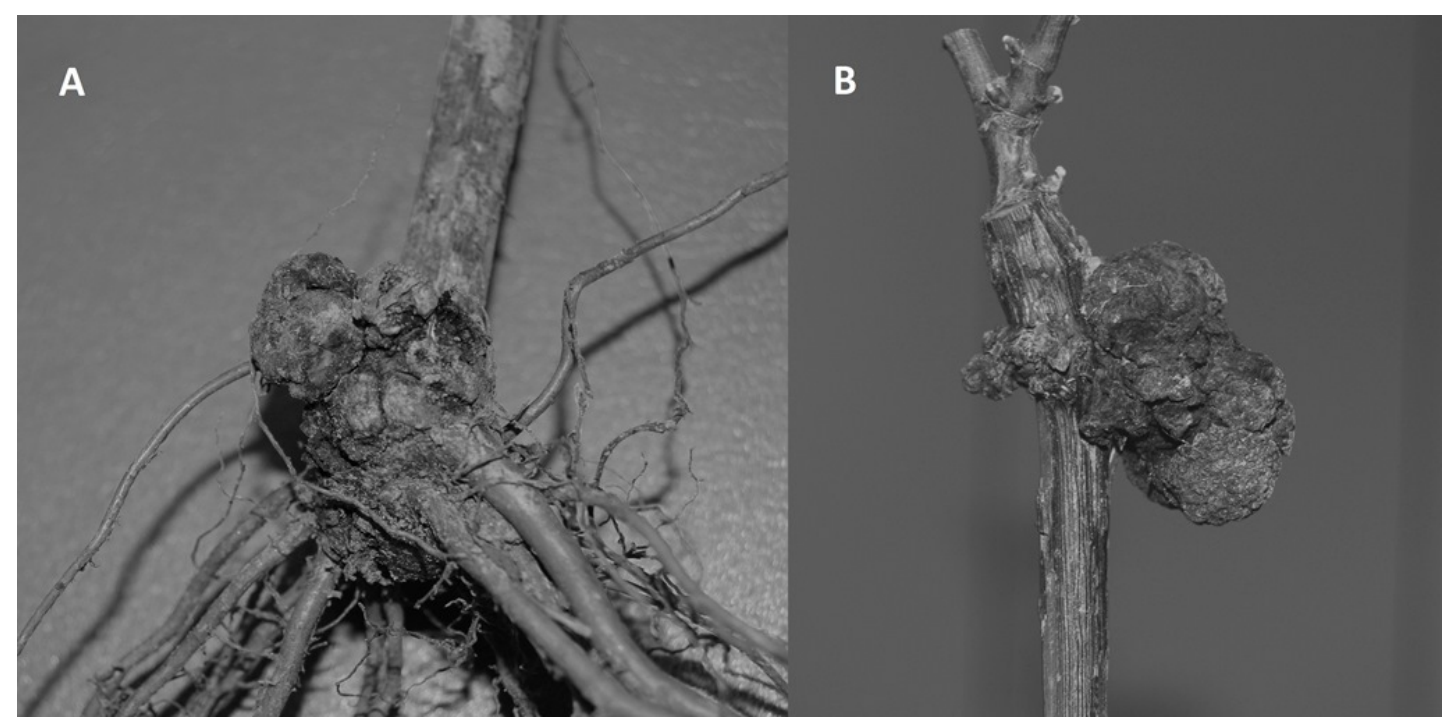

Figure 1: Grapevine grafts showing crown gall symptoms on a heel (A) and on a graft union (B) (Photos: I. Zidarič).

\subsection{Identification of $A$. vitis}

A. vitis isolates were identified based on polygalacturonase gene amplification (pehA) and multiplex PCR (Pulawska et al., 2006). Repeatability of the PCR results on the same DNA samples was verified in 2013 .

\subsubsection{Polygalacturonase gene amplification}

The pehA PCR was performed in a total volume of $25 \mu \mathrm{l}$ applying the protocol of Eastwell et al. (1995). For the PCR reaction, $1 \mu$ l of bacterial DNA template was used for PCR amplification in $1 \times$ PCR Buffer (Promega), $2.0 \mathrm{mM} \mathrm{MgCl} 2,0.1 \mu \mathrm{M}$ each pehA primer (Table 1), $0.2 \mathrm{mM}$ dNTPs,
0.25 U GoTaq Flexi DNA Polymerase (Promega). The thermal cycler was programmed for an initial denaturation at $95{ }^{\circ} \mathrm{C}$ for $3 \mathrm{~min}$ followed by 40 cycles of amplification $\left(95^{\circ} \mathrm{C}\right.$ for $1 \mathrm{~min}, 55^{\circ} \mathrm{C}$ for $1 \mathrm{~min}, 72{ }^{\circ} \mathrm{C}$ for $1.5 \mathrm{~min}$ ) with $5 \mathrm{~min}$ of final elongation at $72{ }^{\circ} \mathrm{C}$. The amplified fragments of $205 \mathrm{bp}$ were visualized on $2 \%$ agarose gel.

\subsubsection{Multiplex PCR}

The multiplex PCR was performed in a $15 \mu 1$ reaction volume applying the protocol of Pulawska et al. (2006). All reactions were performed in $1 \times$ PCR buffer (Promega), $1.5 \mathrm{mM} \mathrm{MgCl} 2,1 \mu \mathrm{M}$ each primer (UF, B1R, B2R and AvR) (Table 1), $0.2 \mathrm{mM}$ dNTPs and 1.0 U GoTaq Flexi DNA 
Polymerase (Promega). The amplification conditions comprised an initial denaturation at $95^{\circ} \mathrm{C}$ for $1 \mathrm{~min}$, followed by 35 cycles of denaturation at $94{ }^{\circ} \mathrm{C}$ for $1 \mathrm{~min}$, annealing at $67^{\circ} \mathrm{C}$ for $1 \mathrm{~min}$, extension at $72{ }^{\circ} \mathrm{C}$ for $1.5 \mathrm{~min}$ and a final extension step at $72{ }^{\circ} \mathrm{C}$ for $10 \mathrm{~min}$. The amplified PCR fragments were visualized on a $2 \%$ agarose gel. Strains belonging to $A$. tumefaciens gave a $184 \mathrm{bp}$ product and those belonging to $A$. vitis gave a 478 bp product (Figure 2).

\subsection{Assessing tumor-inducing capacity}

Diagnosis of pathogenic strains of Agrobacterium spp. is carried out biologicaly on wounded test plants and molecularly through detection of bacterial tumour-inducing plasmid (pTi) responsible for uncontrolled plant cell growth.

\subsubsection{Pathogenicity tests}

The pathogenicity of Agrobacterium strains was determined on tomato, sunflower and kalanchoe plants. Young, four-week-old seedlings were punctured three times in the stem using a sterile entomological needle dipped in pure culture colonies grown on $\mathrm{KB}$ medium for 24 hours at
$27{ }^{\circ} \mathrm{C}$. Tests were performed in triplicates. Inoculated seedlings were maintained in a glasshouse at $20-30{ }^{\circ} \mathrm{C}$ with natural lighting conditions. In the period of 3 to 6 weeks post inoculation, the plants were visually inspected for tumor formations every few days. The strains C58 and 339-26 were used as positive controls; strain K84 and water served as negative controls. The test was completed in 2007.

\subsection{2 pTi detection}

The PCR was performed in a $25 \mu 1$ reaction volume applying the protocol of Suzaki et al. (2004). For the PCR reaction, $2 \mu 1$ of bacterial DNA template (diluted $1000 \times$ ) were used for PCR amplification in $1 \times$ PCR Buffer (Promega), $1.5 \mathrm{mM} \mathrm{MgCl}, 0.5 \mu \mathrm{M} \mathrm{VCF} 3$ and VCR3 primers (Table 1), $0.2 \mathrm{mM}$ dNTPs, 0.5 U GoTaq Flexi DNA Polymerase (Promega). The thermal cycler was programmed with an initial denaturation at $94{ }^{\circ} \mathrm{C}$ for $5 \mathrm{~min}$ followed by 35 cycles of amplification $\left(94{ }^{\circ} \mathrm{C}\right.$ for $1 \mathrm{~min}, 56{ }^{\circ} \mathrm{C}$ for $1 \mathrm{~min}$, $72{ }^{\circ} \mathrm{C}$ for $1 \mathrm{~min}$ ) with $5 \mathrm{~min}$ of final elongation at $72{ }^{\circ} \mathrm{C}$. The amplified fragments of $414 \mathrm{bp}$ were visualized on $2 \%$ agarose gel (Figure 2).

Table 1: Primers pair sequences used in our study.

\begin{tabular}{lll} 
Primer & Sequence & Reference \\
\hline pehAF & 5'-CGATGGCGGCGAGGATTT-3' & Eastwell et al., 1995 \\
pehAR & 5'-ATCGGGCGTGAAACAAGT-3' & \\
UF f & 5'-GTAAGAAGCGAACGCAGGGAACT-3' & Pulawska et al., 2006 \\
B1R r & 5'-GACAATGACTGTTCTACGCGTAA-3' & \\
B2R r & 5'-TCCGATACCTCCAGGGCCCCTCACA-3' & \\
AvR r & 5'-AACTAACTCAATCGCGCTATTAAC-3' & \\
VCF3 & 5'-GGCGGGCGYGCYGAAAGRAARACYT-3' & Suzaki et al., 2004 \\
VCR3 & 5'-AAGAACGYGGNATGTTGCATCTYAC-3' & \\
\hline
\end{tabular}

\subsection{Data analysis}

Agreement between PCR and pathogenicity test was evaluated by calculating positive and negative percent agreement with respect to imperfect reference standard, in our case the pehA method and the biological pathogenicity test. The agreement indices were calculated from twodimensional contingency table shown in Table 2 . 
Table 2: Two-dimensional contingency table for calculating agreement indices between two methods.

\begin{tabular}{r|cc} 
& \multicolumn{2}{|c}{ Standard method A } \\
Method B & positive & negative \\
\hline positive & $\mathrm{a}$ & $\mathrm{b}$ \\
negative & $\mathrm{c}$ & $\mathrm{d}$ \\
\hline Total & $(\mathrm{a}+\mathrm{c})$ & $(\mathrm{b}+\mathrm{d})$
\end{tabular}

Positive percent agreement with respect to imperfect reference standard was calculated according to equation (1) and was interpreted as sensitivity (Se) of the method. Similarly, negative percent agreement with respect to imperfect standard was calculated according to equation (2) and was interpreted as specificity ( $\mathrm{Sp}$ ) of the method. For estimation of confidence limits the
$95 \%$ confidence interval (CI) was calculated where appropriate.

$$
\begin{aligned}
& \mathrm{Se}=(a / a+c) \cdot 100 \% \\
& \mathrm{Sp}=(d / b+d) \cdot 100 \%
\end{aligned}
$$

\section{RESULTS AND DISCUSSION}

\subsection{Identification of $A$. vitis by pehA or multiplex PCR method}

Morphologically, most rhizobial colonies appeared similar to one another on a general media. Therefore, it is imperative to use selective media for isolation of $A$. vitis. On $3 \mathrm{DG}$ medium, A. vitis colonies were visible sooner (after 3 days at $27^{\circ} \mathrm{C}$ ) than colonies of $A$. tumefaciens and $R$. rhizogenes, which also had different colony morphologies on $3 \mathrm{DG}$ medium. Where no typical A. vitis colonies were found, we selected for colonies that predominated on 3DG medium.

From 87 grapevine grafts we obtained 80 Agrobacterium isolates. According to multiplex PCR (Pulawska et al., 2006) 75 isolates were identified as $A$. vitis and five as $A$. tumefaciens. The number of identified $A$. vitis strains was compared to the number of pehA positive (A. vitis) strains. There was a perfect agreement (100 \%) between the two methods. All pehA positive isolates had an A.vitis-diagnostic band of $478 \mathrm{bp}$ in multiplex PCR. The results were verified in 2013 on the same DNA samples stored at $-20^{\circ} \mathrm{C}$.

Our diagnostic laboratory has completely replaced the pehA identification method with multiplex PCR as it distinguishes between $A$. vitis and $A$. tumefaciens and differentiates them from other rhizobia in the Rhizobiaceae family in one reaction. 


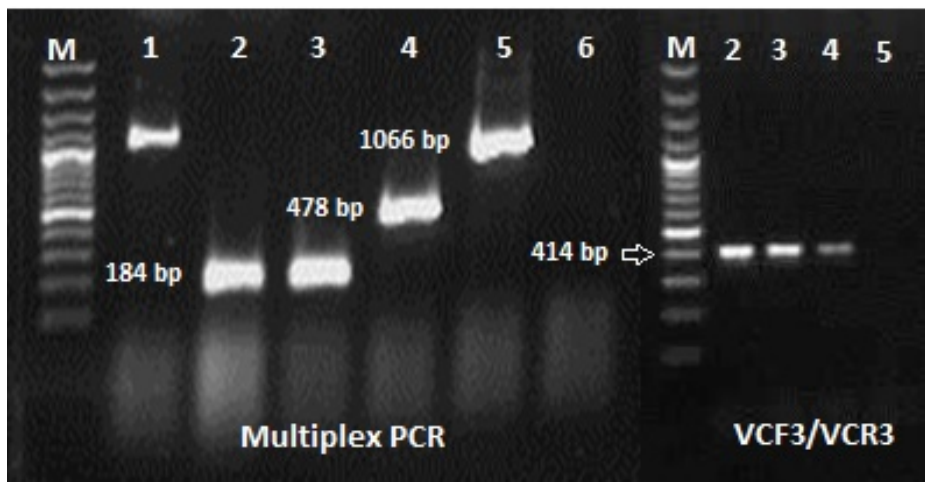

Figure 2: Agarose gel electrophoresis of diagnostic fragments from multiplex and VCF3/VCR3 PCR; M (ladder), 1 (unknown soil isolate), 2 (grapevine isolate), 3 (C58, A. tumefaciens), 4 (339-26, A. vitis), 5 (K84, R. rhizogenes), and 6 (water).

\subsection{Pathogenicity status and pTi detection}

All 80 isolates were tested for pathogenicity and abilitiy to cause tumors on stems of inoculated plants. This is a standard method for diagnosis of tumor-inducing strains and detection of latent infections (Janse, 2005). Almost $70 \%$ of the strains were found pathogenic. One pathogenic strain was identified as A. tumefaciens causing tumors on all three test plants. In 2013 we analysed the same strains for the presence of pTi. We used a PCR method for identification of pathogenic and non-pathogenic strains of agrobacteria using primers VCF3/VCR3 with improved specificity
(Suzuki et al., 2004). All strains with detected pTi were identified as $A$. vitis by multiplex PCR. The agreement between results from pathogenicity tests and pTi detection method was not exact (Table 3). The sensitivity of VCF3/VCR3 primer pair was $89.1 \%$ with six false negatives (Table 4 ). The only pathogenic A. tumefaciens strain was one of them. However, the specificity was $100 \%$ with no false positives. The VCF3/VCR3 results were most compatible with pathogenicity assessment on kalanchoe and tomato test plants, though specificity was higher on kalanchoe plants (Table $4)$.

Table 3: Summary of results by two methods for Agrobacterium spp. pathogenicity assessment.

\begin{tabular}{|c|c|c|c|}
\hline VCF3/VCR3 & $\begin{array}{l}\mathrm{Pa} \\
+\end{array}$ & $\begin{array}{l}\text { st } \\
\text { - }\end{array}$ & Total \\
\hline+ & 49 & 0 & 49 \\
\hline- & 6 & 25 & 31 \\
\hline Total & 55 & 25 & 80 \\
\hline
\end{tabular}

It is not uncommon for $A$. vitis strains to have different host range even with identical physiological and biochemical characteristics (Tolba and Zaki, 2011). Interestingly, results from Tolba and Zaki (2011) indicate tomato as an unreliable test plant giving positive results on pathogenic $A$. vitis strains in only 5 of 12 isolates. At the same time, test on tomato proved specific for certain strains that caused tumors only on grapevines. In our case, none of the grapevine strains caused tumors specifically on tomato. On the other hand, six strains caused tumors solely on sunflower, and two solely on kalanchoe test plants.
The presence of pTi was diagnosed on only half of these strains (three and one). One possible explanation is the sensitivity of the primers. These might be affected by high genetic diversity within pathogenic agrobacteria which could result in false negatives.The use of a set of three plants proved crucial in pathogenicity determination, as few of the pathogenic strains exhibited preference toward one host plant. If we had used only tomato or sunflower test plants, we would have observed fewer pathogenic strains and determined lower specificity of the VCF3/VCR3 PCR method in comparison to pathogenicity test results (Table 4). 
Table 4: Sensitivity (Se) and specificity ( $\mathrm{Sp}$ ) of VCF3/VCR3 primer pair with respect to pathogenicity test on test plants.

\begin{tabular}{r|ccc|l}
\multicolumn{1}{l|}{} & \multicolumn{3}{|c|}{ Test plant } & \\
VCF3/VCR3 & tomato & sunflower & kalanchoe & Overall \\
\hline Se & 95.1 & 89.1 & 95.7 & 89.1 CI [82.27; 95.93] \\
Sp & 74.4 & 76.5 & 85.3 & 100 \\
\hline
\end{tabular}

The biological pathogenicity test is laborious and time-consuming. Pathogenicity is affected by environmental factors like temperature (Hamilton and Fall, 1971) and plant age (Binns and Thomashow, 1988). Also, the absence of tumors does not necessarily imply the absence of pTi. This is where molecular methods provide an additional confirmation. We repeated pathogenicity tests three times in three different seasons (spring, summer and autumn) using young to mature plants (results not shown). The most consistent results were obtained on young plants in late spring and early autumn when the average air temperature in the greenhouse was around $25{ }^{\circ} \mathrm{C}$. Also, the interpretation can be doubtful when the PCR shows the absence of pTi, but the test plants develop tumors. Although PCR techniques for simultaneous identification of pathogenic and nonpathogenic $A$. vitis are available (Kawaguchi et al., 2005), the traditional pathogenicity test is still a standard technique in strain pathogenicity determination.

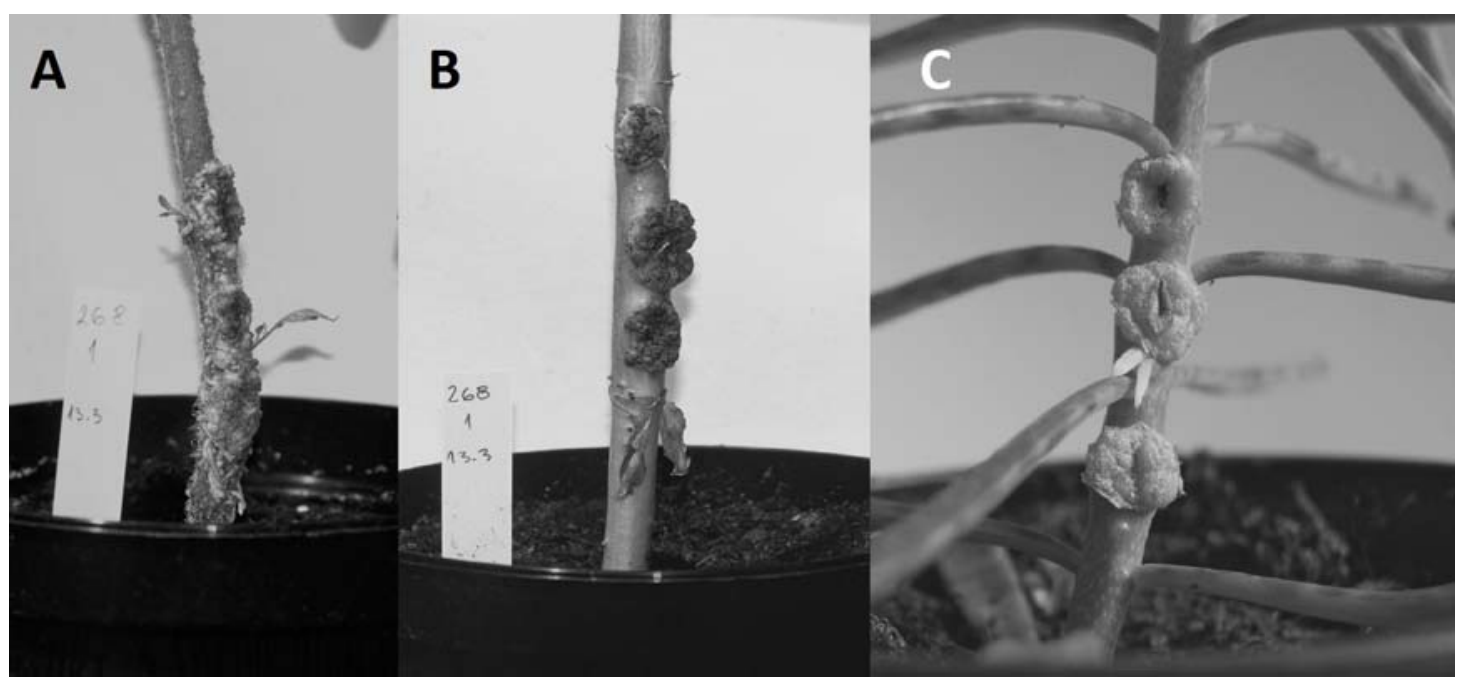

Figure 3: Pathogenicity tests on tomato (A), sunflower (B) and kalanchoe (C) plants (Photos: I. Zidarič).

\section{CONCLUSION}

Pathogenic $A$. vitis strains predominated among isolates of $A$. vitis from Slovenian grapevine grafts. Only one strain of A. tumefaciens was found pathogenic. In identification of $A$. vitis we obtained matching results using pehA or multiplex PCR primers. Therefore, we suggest using multiplex PCR (Pulawska et al., 2006) for reliable identification of $A$. vitis and A. tumefaciens on grapevine. Further, we detected most of the pathogenic strains with VCF3/VCR3 primers. Based on our results, one might conclude that VCF3/VCR3 PCR could replace pathogenicity tests, but due to the false negatives, we conclude that biological pathogenicity test is still an invaluable tool in plant bacteriology. 


\section{ACKNOWLEDGEMENTS}

This work was supported by the Slovenian

Research Agency (Grant No. V4-0313).

\section{REFERENCES}

Binns A.N., Thomashow M.F. 1988. Cell biology of agrobacterium infection and transformation of plants. Annual Review of Microbiology, 42: 575606. DOI: 10.1146/annurev.mi.42.100188.003043

Brisbane P.G., Kerr A. 1983. Selective media for the three biovars of Agrobacterium. Journal of Applied Bacteriology, 54, 3: 425-431. DOI: 10.1111/j.13652672.1983.tb02638.x

Conn H.J. 1942. Validity of the genus Alcaligenes. Journal of Bacteriology, 44: 353-360

De Cleene M., De Ley J. 1976. The host range of crown gall. Botanical Review, 42: 389-466. DOI: 10.1007/BF02860827

Eastwell K.C., Willis L.G., Cavileer T.D. 1995. A rapid and sensitive method to detect Agrobacterium vitis in grapevine cuttings using polymerase chain reaction. Plant Disease, 79: 822-827. DOI: 10.1094/PD-79-0822

Epstein L., Kaur S., McKenna J.R., Grant J.A., Olson W., Reil W.O. 2008. Crown gall can spread between walnut trees in nurseries and reduce future fields. California Agriculture, 62: 111-115. DOI: 10.3733/ca.v062n03p111

Escobar, M.A., Dandekar, A.M. 2003. Agrobacterium tumefaciens as an agent of disease. Trends in Plant Science, 8, 8: 380 - 386. DOI: 10.1016/S13601385(03)00162-6

Fabjančič E., Milevoj L. 2003. Characteristics of the bacterium Agrobacterium vitis isolated from Slovenian vineyards $=$ Značilnosti bakterije Agrobacterium vitis izolirane iz vinske trte v slovenskih vinogradih. Zbornik Biotehniške fakultete Univerze v Ljubljani, Kmetijstvo, Agricultural issue, ISSN 1408-340X , 81, 1: 3-13

Farrand S.K., van Berkum P., Oger P. 2003. Agrobacterium is a definable genus of the family Rhizobiaceae. International Journal of Systematic and Evolutionary Microbiology, 53: 1681-1687. DOI: 10.1099/ijs.0.02445-0

Hamilton R.H., Fall M.Z. 1971. The loss of tumorinducing ability in Agrobacterium tumefaciens by incubation at high temperature. Experientia, 27: 229-230. DOI: 10.1007/BF02145913
Holt J.G., Krieg N.R., Sneath P.H.A., Staley J.T., Williams S.T. 1994. Bergey's Manual of Determinative Bacteriology, 9th edn. Williams \& Wilkins Comp., Baltimore, MD, USA

Janse J.D. 2005. Phytobacteriology:principles and practice. CABI Publishing, Wallingford, UK. DOI: 10.1079/9781845930257.0000

Kawaguchi A., Sawada H., Inoue K., Nasu H. 2005. Multiplex PCR for the identification of Agrobacterium biovar 3 strains. Journal of Plant Pathology, 71: 54-59. DOI: 10.1007/s10327-0040160-5

Kennedy B.W., Alcorn S.M. 1980. Estimates of U.S. crop losses to prokaryote plant pathogens. Plant Disease, 64: 674-676. DOI: 10.1094/PD-64-674

Kumagai L., Fabritius A.L. 2008. Detection and differentiation of pathogenic Agrobacterium vitis and $A$. tumefaciens in grapevine using multiplex bio-PCR. Proceedings of the $2^{\text {nd }}$ Annual National Viticulture Research Conference, July 9-11, 2008, University of California, Davis: 42-43

Lindström K., Young J.P.W. 2011. International Committee on Systematics of ProkaryotesMinutes: Subcommittee on the taxonomy of Agrobacterium and Rhizobium. International Journal of Systematic and Evolutionary Microbiology, 61: 3089-3093

Mougel C., Thioulouse J., Perrière G., Nesme X. 2002. A mathematical method for determining genome divergence and species delineation using AFLP. International Journal of Systematic and Evolutionary Microbiology, 52, 2: 573-586

Ophel K., Kerr A. 1990. Agrobacterium vitis sp. nov. for strains of Agrobacterium biovar 3 from grapevines. International Journal of Systematic and Evolutionary Micriobiology, 40, 3: 236-241

Poncet C., Antonini C., Bettachini A., Hericher D., Pionnat S., Simonini L., Dessaux Y., Nesme X. 1996. Impact of the crown gall disease on vigour and yield of rose trees. Acta Horticulturae, 424: 221-225

Portier P., Fisher-Le Saux M., Mougel C., Lerondelle C., Chapulliot D., Thioulouse J., Nesme X. 2006. Identification of genomic species of Agrobacterium 
biovar 1 by AFLP genomic markers. Applied Environmental Microbiology, 72: 7123-7131. DOI: 10.1128/AEM.00018-06

Pulawska J. 2010. Crown gall of stone fruits and nuts economic significance and diversity of its causal agent tumorigenic Agrobacterium spp. Journal of Plant Pathology, 92: 87-98

Pulawska J., Kalužna M. 2012. Phylogenetic relationship and genetic diversity of Agrobacterium spp. isolated in Poland based on gyrB gene sequence analysis and RAPD. European Journal of Plant Pathology, 133: 379-390. DOI: 10.1007/s10658-011-9911-2

Pulawska J., Willems A., Sobiczewski P. 2006. Rapid and specific identification of four Agrobacterium species and biovars using multiplex PCR. Systematic and Applied Microbiology, 29: 470479. DOI: $10.1016 /$ j.syapm.2005.11.002

Riker A.J. Banfield W.M., wright W.H., Keitt G.W., Sagen H.E. 1930. Studies on infectious hairy root of nursery apple trees. Journal of Agricultural Research, 41: 507-540

Sambrook J., Fritsch E.F., Maniatis T. 1989. Molecular cloning, A laboratory manual, 2nd edn. Cold Spring Harbor Laboratory Press, Cold Spring Harbor, NY.

Sawada H., Ieki H., Matsuda I. 1995. PCR detection of Ti and Ri plasmid from phytopathogenic Agrobacterium strains. Applied Environmental Microbiology, 61: 828-831

Schroth M.N., Weinhold A.R., McCain A.H., Hildebrand D.C., Ross N. 1971. Biology and control of Agrobacterium tumefaciens. Hilgardia, 40: $537-552$

Shams M., Campillo T., Lavire C., Muller D., Nesme X., Vial L. 2012. Rapid and efficient methods to isolate, type strains and determine species of Agrobacterium spp. in pure culture and complex environments.Biochemical Testing, InTech: 1-20

Smith E.F., Townsend C.O. 1907. A plant-tumor of bacterial origin. Science, 25: 671-673. DOI: 10.1126/science.25.643.671
Suzaki K., Yoshida K., Sawada H. 2004. Detection of tumorigenic Agrobacterium strains from infected apple saplings by colony PCR with improved PCR primers. Journal of General Plant Pathology, 70, 6: 342-347. DOI: 10.1007/s10327-004-0133-8

Šabec-Paradiž M., Koruza B., Pečar-Fonović U., Škerlevaj V., Topolovec A., Urek G. 2002. Agrobacterium in grapevine nursery production. Vinogradi in vina za tretje tisočletje? (2. slovenski vinogradniško-vinarski kongres z mednarodno udeležbo, Otočec, 31.1. do 2.2. 2002), Ljubljana: 203-205

Tolba I.H., Zaki M.F. 2011. Characterization of Agrobacterium vitis isolates obtained from galled grapevine plants in Egypt. Annals of Agricultural Science, 56, 2: 113-119. DOI: 10.1016/j.aoas.2011.06.001

Van Larebeke N., Engler G., Holsters M., Van den Elsacker S., Zaenen I., Schilperoort R.A., Schell J. 1974. Large plasmid in Agrobacterium tumefaciens essential for crown gall inducing activity. Nature (London) 252: 169-170. DOI: 10.1038/252169a0

Watson B., Currier T.C., Gordon M.P., Chilton M.-D., Nester E.W. 1975. Plasmid required for virulence of Agrobacterium tumefaciens. Journal of Bacteriology, 123:255-264

Young J.M., Kuykendall L.D., Martinez-Romero E., Kerr A., Sawada H. 2001. A revision of Rhizobium Frank 1889, with an emended description of the genus, and the inclusion of all species of Agrobacterium Conn 1992 and Allorhizobium undicola de Lajudieet al. 1998 as new combinations: Rhizobium radiobacter, $R$. rhizogenes, $R$. rubi, $R$. undicola and $R$. vitis. International Journal of Systematic and Evolutionary Microbiology, 51: 89-103

Young J.M., Pennycook S.R., Watson D.R.W. 2006. Proposal that Agrobacterium radiobacter has priority over Agrobacterium tumefaciens. Request for an Opinion. International Journal of Systematic and Evolutionary Microbiology, 56, 2: 491-493. DOI: $10.1099 /$ ijs.0.64030-0 